\title{
Variation in the wood properties of coast redwood trees in New Zealand
}

\author{
Trevor G Jones ${ }^{1 *}$, Charlie B Low², Diahanna R O'Callahan² and Colleen M Chittenden ${ }^{2}$
}

\begin{abstract}
Background: There is wide variation in the wood properties of plantation-grown coast redwood (Sequoia sempervirens (D.Don) Endl.) in New Zealand. Contributing factors are the seed source, silviculture, growth rate and age of the trees in the plantation forests. Little is known about how these factors affect the variation of wood properties among and within the trees of New Zealand's coast redwood forests.

Methods: The wood of plantation-grown coast redwood trees from three forests in the North Island, New Zealand, was evaluated using butt log and breast height discs and cores, and in vitro decay tests with brown- and white-rot fungal cultures, to determine the variation in the heartwood content, basic density, and red colour and natural durability of the heartwood.

Results: The heartwood content of the coast redwood trees was strongly influenced by the age and size of the trees. The basic density of the wood varied widely among the trees in the forests. There were strong radial trends of heartwood colour and natural durability within the stems of trees, with differences among trees at the same growth rings. The heartwood showed a wide range of natural durability, with trees from the older forest stands having a higher proportion of durable heartwood.

Conclusions: The diameter growth and age of the coast redwood trees, and the variation among and within the stems of trees will affect the wood properties. Faster diameter growth is likely to increase the heartwood content, and longer rotations will increase the quantity of durable heartwood. The variation among trees suggests there is potential for genetic improvement.
\end{abstract}

Keywords: Sequoia sempervirens; Heartwood; Colour; Density; Durability

\section{Background}

The plantation-grown resource of coast redwood (Sequoia sempervirens (D.Don) Endl.) in New Zealand occurs largely in the North Island (Knowles and Miller 1993), and comprises forest stands of trees from both Californian and New Zealand seed sources, and sites with different soil and climatic conditions. The growth of coast redwood trees across a range of North Island sites in New Zealand is appreciably faster than in California (Brown 2007), with mean annual increments of over 30 cubic metres per hectare on good quality sites, that could allow for rotation lengths of around 35 years (Dean 2007). The wood of New Zealand-grown coast redwood varies widely in quality, due to the seed source, silviculture, growth and age of the trees,

\footnotetext{
* Correspondence: trevor.jones@plantandfood.co.nz

${ }^{1}$ The New Zealand Institute for Plant \& Food Research Limited, Private Bag 11600, Palmerston North 4442, New Zealand

Full list of author information is available at the end of the article
}

but it can compare favourably with second-growth coast redwood in California (Knowles and Miller 1993; Cown 2008; Cown et al. 2013).

Coast redwood trees in the North Island of New Zealand have a heartwood content that averaged 54\% (range 44-66\%) for 38 year-old trees from Mangatu Forest in Gisborne (Cown and McKinley 2009), and 52\% (range 45-62\%) for 45-year-old trees from Tauranga in the Bay of Plenty (Colbert and McConchie 1983). The basic density of the wood was low, and averaged $323 \mathrm{~kg} \mathrm{~m}^{-3}$ (range $262-380 \mathrm{~kg} \mathrm{~m}^{-3}$ ) for the 38-year-old trees from Mangatu Forest (Cown and McKinley 2009), and $353 \mathrm{~kg} \mathrm{~m}^{-3}$ (range $282-388 \mathrm{~kg} \mathrm{~m}^{-3}$ ) for the 45 -yearold trees from Tauranga (Colbert and McConchie 1983). This was similar to the basic density of second-growth coast redwood trees in California, with average values of $340 \mathrm{~kg} \mathrm{~m}^{-3}$ (Bendtsen 1966), 356 and $360 \mathrm{~kg} \mathrm{~m}^{-3}$ for

\section{它}

(c) 2014 Jones et al.; licensee Springer. This is an Open Access article distributed under the terms of the Creative Commons Attribution License (http://creativecommons.org/licenses/by/2.0), which permits unrestricted use, distribution, and reproduction in any medium, provided the original work is properly cited. 
close-grown trees (Luxford and Markwardt 1932; Markwardt and Wilson 1935), $400 \mathrm{~kg} \mathrm{~m}^{-3}$ (range 270$550 \mathrm{~kg} \mathrm{~m}^{-3}$ ) for 45 - to 65-year-old close-grown trees (Resch and Arganbright 1968), $340 \mathrm{~kg} \mathrm{~m}^{-3}$ (range 270$410 \mathrm{~kg} \mathrm{~m}^{-3}$ ) for butt and second logs of 65-year-old trees (Fritz 1950).

The heartwood of New Zealand-grown coast redwood trees has been shown in field tests to be moderately durable in ground contact, and durable in above-ground situations (Hughes 1982). Weatherboard tests of the heartwood of coast redwood in New Zealand have shown $84 \%$ of weatherboards to be sound for test periods of 9 to 17 years, indicating there is variability in the natural durability of this species (Page et al. 1997). One of the features of coast redwood is the natural durability of its heartwood, but the durability of New Zealand-grown coast redwood is quite variable (Nicholas 2008). Old-growth and second-growth coast redwood trees in California have shown large differences in the natural durability of heartwood (Clark and Scheffer 1983). The differences occurred among forest locations and individual trees, and within the stems of trees. The second-growth trees (24 to 100 year-old) were less resistant and more variable in natural durability, compared with the old-growth trees (200 to 1300 year-old) (Clark and Scheffer 1983). The natural durability varied from the inner to outer heartwood within the tree stems, with the most durable heartwood occurring adjacent to the sapwood, and the susceptibility to decay increasing towards the pith (Sherrard and Kurth 1933; Clark and Scheffer 1983).

In this study, the wood of plantation-grown coast redwood trees from three forests in the North Island of New Zealand was evaluated to determine the effect that forest sites, and trees of different seed source and age have on the heartwood content, basic density, colour, and natural durability of the heartwood. Butt log and breast height discs and cores, and in vitro decay testing of heartwood blocks with brown- and white-rot fungal cultures, were used to assess the wood properties and the variation that occurred among the forest sites, trees in the forest stands, and within the tree stems.

\section{Methods}

\section{Coast redwood stands}

The coast redwood trees were sampled from stands at Kinleith Forest in the Waikato, Mangatu Forest in Gisborne, and Rotoehu Forest in the Bay of Plenty (Table 1). The trees in each forest stand were of different ages and seedlots, so the effects of site and genetics are confounded, but the stands did provide a wide range of tree age and New Zealand and Californian seedlots. The 71-year-old Kinleith Forest stand was grown from a Californian seedlot, the 38-year-old Mangatu Forest stand was from a New Zealand seedlot from Whakarewarewa Forest in the Bay of Plenty, and the 22-year-old Rotoehu Forest stand was a coast redwood provenance trial, with eight seedlots from California (latitude range $36^{\circ} 59^{\prime}$ to $40^{\circ} 53^{\prime}$ ) and a New Zealand seedlot from Whakarewarewa Forest in the Bay of Plenty.

The stand inventories showed the Kinleith Forest stand had a stand density of 550 stems ha ${ }^{-1}$, basal area of $150.9 \mathrm{~m}^{2} \mathrm{ha}^{-1}$, mean diameter at breast height (DBH) of $59.1 \mathrm{~cm}$, mean top height of $44.9 \mathrm{~m}$, and the Mangatu Forest stand had a stand density of 398 stems ha ${ }^{-1}$, basal area of $107.6 \mathrm{~m}^{2} \mathrm{ha}^{-1}$, mean diameter at breast height $(\mathrm{DBH})$ of $58.5 \mathrm{~cm}$, and mean height of $32.8 \mathrm{~m}$. The Rotoehu forest stand had an effective ${ }^{\mathrm{a}}$ stand density of 660 stems ha $^{-1}$ at age 20 years (Vincent 2001).

\section{Tree and wood disc measurement}

The trees were measured at breast height $(1.4 \mathrm{~m})$ for diameter over bark, and after felling wood discs were cut from the ends of the $6 \mathrm{~m}$ butt log for six trees at Kinleith and thirteen trees at Mangatu Forest, and at breast height for 32 trees at Rotoehu Forest. The wood basic density was measured gravimetrically for growth rings 21-30 from the pith, using two diametric pith-to-bark sectors cut from each disc at Kinleith and Mangatu Forests, and from pith-to-bark using two breast height increment cores per tree at Rotoehu Forest. The heartwood content was measured as a percentage of the disc area (Haslett and Young 1990).

Table 1 Description of the coast redwood forest stands in the North Island, New Zealand

\begin{tabular}{llll}
\hline & & \multicolumn{2}{c}{ Site } \\
\cline { 2 - 4 } Descriptor & Kinleith Forest & Mangatu Forest & Rotoehu Forest \\
\hline Year planted & 1932 & 1970 & 1981 \\
Latitude & $38^{\circ} 04^{\prime}$ & $38^{\circ} 16^{\prime}$ & $37^{\circ} 54^{\prime}$ \\
Longitude & $175^{\circ} 54^{\prime}$ & $177^{\circ} 51^{\prime}$ & $176^{\circ} 32^{\prime}$ \\
Elevation, $\mathrm{m}$ & 240 & 200 & 120 \\
Average annual temperature, ${ }^{\circ} \mathrm{C}$ & 12.7 & 13.2 & 13.4 \\
Average annual rainfall, $\mathrm{mm}$ & 1740 & 1368 & 1764 \\
Soil series and type & Mamaku sand & & Ohinepanea sand \\
\hline
\end{tabular}




\section{Preparation of blocks for durability tests}

The coast redwood heartwood blocks for colour measurement and decay testing were prepared from the butt log and breast height wood discs. Two pith-to-bark strips were cut from each wood disc at the bottom of the butt logs at Mangatu Forest, and one pith-to-bark strip was cut from each of the wood discs at the top and bottom of the butt logs at Kinleith Forest, and from each breast height wood disc at Rotoehu Forest. Heartwood blocks of dimensions $25 \times 15 \times 50 \mathrm{~mm}$ (tangential, radial, longitudinal directions) were cut in series from the inner to outer heartwood of each pith-to-bark strip. The average growth ring number from the pith was measured for each heartwood block.

Radiata pine (Pinus radiata D. Don) sapwood blocks of dimensions $25 \times 15 \times 50 \mathrm{~mm}$ (tangential, radial, longitudinal directions) were cut for use as controls.

\section{Colour measurement}

The $\mathrm{a}^{*}$ colour was measured using the CIELAB colour space standard (CIE 2007) on the radial longitudinal surfaces of the coast redwood heartwood blocks using a Minolta CR-400 Chroma meter (Konica Minolta Sensing, Inc., Osaka, Japan). Three spot (8 mm diameter) measurements were made on each radial longitudinal surface (total of six spot measurements per block) and averaged.

\section{Decay testing}

The fungal decay resistance of the coast redwood heartwood blocks, and radiata pine sapwood control blocks, was evaluated using pure fungal culture decay testing with the European Standards EN 113 (1996) and EN 350-1 (1994). The fungal cultures used were: brown-rots Coniophora puteana (Schumach.) P. Karst. (strain BAM Ebw 15) (CABI UK Centre, Egham, UK) and Gloeophyllum trabeum (Pers.) Murrill (strain BAM Ebw 109) (BRE, Watford, UK), and white-rot Trametes versicolor (L.) Lloyd (strain CTB 863 A) (CABI UK Centre, Egham, UK). The heartwood blocks of each pith-to-bark strip were allocated from inner to outer heartwood to the fungal cultures in the repeating sequence: C. puteana, G. trabeum, T. versicolor. There were 150 heartwood blocks from each of Mangatu and Rotoehu Forest, and 108 heartwood blocks from Kinleith Forest.

A further six replicate heartwood blocks from each forest were used to calculate the theoretical oven-dry mass of the test blocks prior to decay testing, and another four replicate heartwood blocks from each forest were used as a check test specimen for calculation of the correction value (EN 113 1996). The check-test specimens were placed in uninoculated culture vessels to determine the variations in the mass of the test blocks resulting from factors other than attack by the test fungal cultures. The radiata pine sapwood blocks were used as the reference species and virulence control specimens, with eight replicates allocated randomly to each of the three fungal cultures.

The brown- and white-rot fungal cultures were grown on $2 \%$ malt extract (Danisco) and $1.5 \%$ bacteriological agar (Coast Biologicals Ltd) for 2 to 3 weeks at $26^{\circ} \mathrm{C}$ and $75 \%$ relative humidity, then transferred to culture vessels containing $4 \%$ malt extract powder and $2 \%$ bacteriological agar. The cultures were allowed to grow for 5 days to 1 week before adding a plastic spacer mat (approximately $64 \times 64 \times 1 \mathrm{~mm}^{3}$ ) with holes drilled in it to allow the fungal hyphae to penetrate through to the heartwood and sapwood blocks, while resisting the transfer of medium to the blocks.

The blocks were re-saturated and leached in water for 14 days, with the leaching water changed every two days (EN 84 1997), air-dried and conditioned to constant weight at $12 \%$ equilibrium moisture content, and weighed, packaged and sterilised by exposure to ethylene oxide gas. Using the EN 113 (1996) procedures, the blocks were placed aseptically into prepared agar containers when the fungal cultures were 2 weeks old. Incubation was for 16 weeks at $26^{\circ} \mathrm{C}$ and $75 \%$ relative humidity (Figure 1).

Following incubation, the blocks were cleaned and weighed, and then oven-dried at $103^{\circ} \mathrm{C}$ for 18 hours. After oven-drying the blocks were reweighed, and the percentage weight loss for each block was calculated along with a theoretical oven-dry weight using the data from the reserved blocks (above). Corrected weights were then calculated using the data from the check control and means were then determined for each fungal culture.

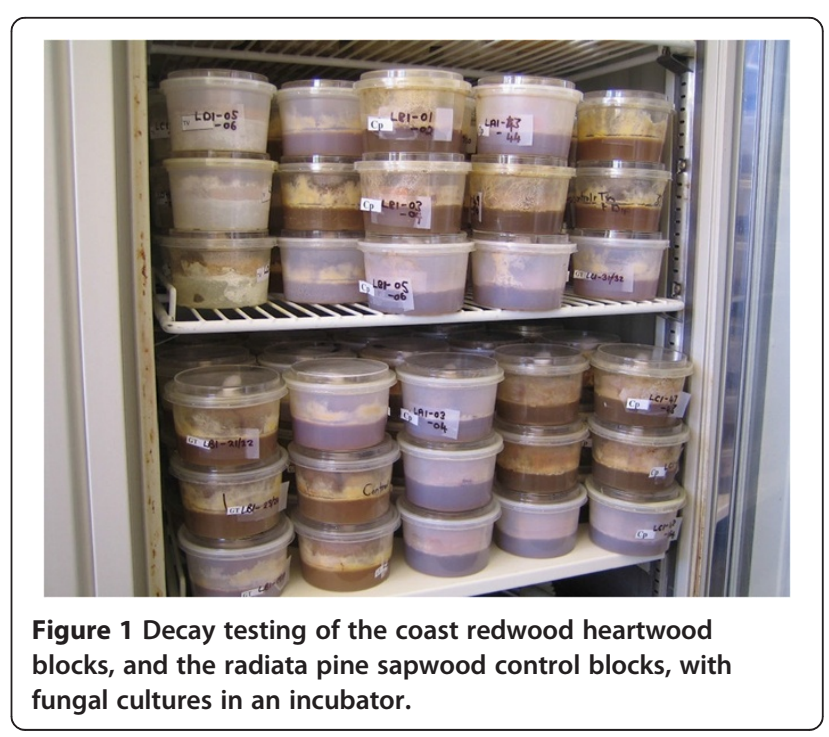


The heartwood blocks were assigned to natural durability classes (Table 2), on the basis of their $\mathrm{x}$ value, calculated using the equation:

$$
\mathrm{x} \text { value }=\frac{\text { average mass loss of the test specimens }}{\text { average mass loss of the reference specimens }}
$$

Where: the test specimens were the coast redwood heartwood blocks, and the reference specimens were the radiata pine sapwood blocks. The $\mathrm{x}$ values were calculated using the fungal culture that contributed the highest weight loss.

\section{Data analysis}

The diameter, heartwood content and $\mathrm{a}^{*}$ colour, basic density, and the weight loss with fungal decay testing, of the coast redwood samples obtained from Kinleith, Mangatu, and Rotoehu Forests were compared using one-way analysis of variance (ANOVA) with the SAS Proc GLM (Version 9.1, SAS Institute Inc., Cary, North Carolina) and the model:

$$
y_{i j}=\mu+f_{i}+t_{j(i)}+e_{i j}
$$

Where: $y_{i j}$ denotes the observation on the tree $j$ in forest $i, \mu$ is the overall population mean, $f_{i}$ represents the effect of the forest site (fixed), $t_{j(i)}$ the effect of the trees (random) nested within the forest, and $e_{i j}$ represents the error term for the measurements. The weight loss with fungal decay testing was positively skewed, so log transformation was used to normalise the distributions.

The SAS Proc GLM MEANS statement and LSD option, which performs pairwise t-tests, equivalent to Fisher's least-significant-difference LSD test in the case of equal cell sizes, was used to provide multiple comparisons of the means at Kinleith, Mangatu, and Rotoehu Forest.

The sources of variation for the diameter, heartwood content and $\mathrm{a}^{*}$ colour, basic density, and heartwood weight loss with fungal decay testing were analysed using the Proc Mixed function of SAS software (Littell et al. 1996) with the model in Equation 2.

The correlation of the heartwood content and the diameter at breast height $(\mathrm{DBH})$ was evaluated using the
Proc Corr function of SAS software, for the Mangatu and Rotoehu Forest trees.

Comparisons of the heartwood $\mathrm{a}^{*}$ colour and weight loss with fungal decay testing for the individual trees of each forest stand were evaluated after adjustment for differences in the radial position from inner to outer heartwood, using analysis of covariance with SAS Proc GLM. The radial position was defined as a proportion of the heartwood radius or the growth ring number from the pith.

\section{Results}

\section{Diameter at breast height}

The diameter at breast height $(\mathrm{DBH})$ of the coast redwood trees selected for felling increased with the age of the forest stands (Table 3, Figure 2). The average DBH $(59.0 \mathrm{~cm})$ of the thirteen felled trees at Mangatu Forest was similar to the stand inventory average $\mathrm{DBH}$ $(58.5 \mathrm{~cm})$. However, the average $\mathrm{DBH}(94.7 \mathrm{~cm})$ of the six felled trees at Kinleith Forest was larger than the stand inventory average DBH $(59.1 \mathrm{~cm})$, indicating that larger trees in the stand had been selected for felling. The forest stands were the largest source of variation in $\mathrm{DBH}$ (Table 4), reflecting the large differences in tree age and the selection of larger trees in the Kinleith Forest stand.

\section{Heartwood content}

The heartwood content of the coast redwood trees increased with the age of the forest stands, and the size of the trees (Table 3, Figures 2 and 3). There were strong correlations between heartwood content and $\mathrm{DBH}$, with coefficients of determination of $\mathrm{R}^{2}=0.48$ and 0.66 for the Mangatu and Rotoehu Forest trees, respectively. The trees selected from the Kinleith Forest stand were larger than the stand average, and given the increase in heartwood content with the size of the trees (Figure 3), this would suggest the heartwood content of the Kinleith Forest trees was higher than expected on average for this stand. The forest stands were the largest source of variation in heartwood content (Table 4), due to the large differences in tree age and size among the forest stands.

Table 2 Natural durability classes of wood fungal attack using fungal culture decay testing, based on European standard EN350-1 (1994)

\begin{tabular}{lll}
\hline Durability class & Description & x value from fungal culture decay testing \\
\hline 1 & Very durable & $x \leq 0.15$ \\
2 & Durable & $x>0.15$ but $\leq 0.30$ \\
3 & Moderately durable & $x>0.30$ but $\leq 0.60$ \\
4 & Slightly durable & $x>0.60$ but $\leq 0.90$ \\
5 & Not durable & $x>0.90$ \\
\hline
\end{tabular}


Table 3 Diameter growth, heartwood content and a* colour of the coast redwood trees, showing forest averages with ranges of tree values in brackets

\begin{tabular}{|c|c|c|c|c|}
\hline Forest & Tree age (years) & Diameter at breast height $(\mathrm{cm})$ & Heartwood content ${ }^{1}(\%)$ & ${\text { Heartwood } a^{*} \text { colour }}^{2}$ \\
\hline Kinleith & 71 & $95(66-111) a$ & $71(67-77) a$ & $14.9(13.6-16.5) \mathrm{a}$ \\
\hline Mangatu & 38 & $59(38-84) b$ & $57(46-70) b$ & $14.8(11.3-17.8) \mathrm{a}$ \\
\hline Rotoehu & 22 & $41(29-67) \mathrm{c}$ & $49(34-69)$ & 14.4 (10.8-16.9) \\
\hline
\end{tabular}

${ }^{1}$ Heartwood content at $6 \mathrm{~m}$ for Kinleith and Mangatu Forest, breast height for Rotoehu Forest.

${ }^{2}$ Heartwood a* colour at $0 \mathrm{~m}$ for Kinleith and Mangatu Forest, and breast height for Rotoehu Forest.

Average values followed by the same letter do not differ significantly $(p>0.05)$.

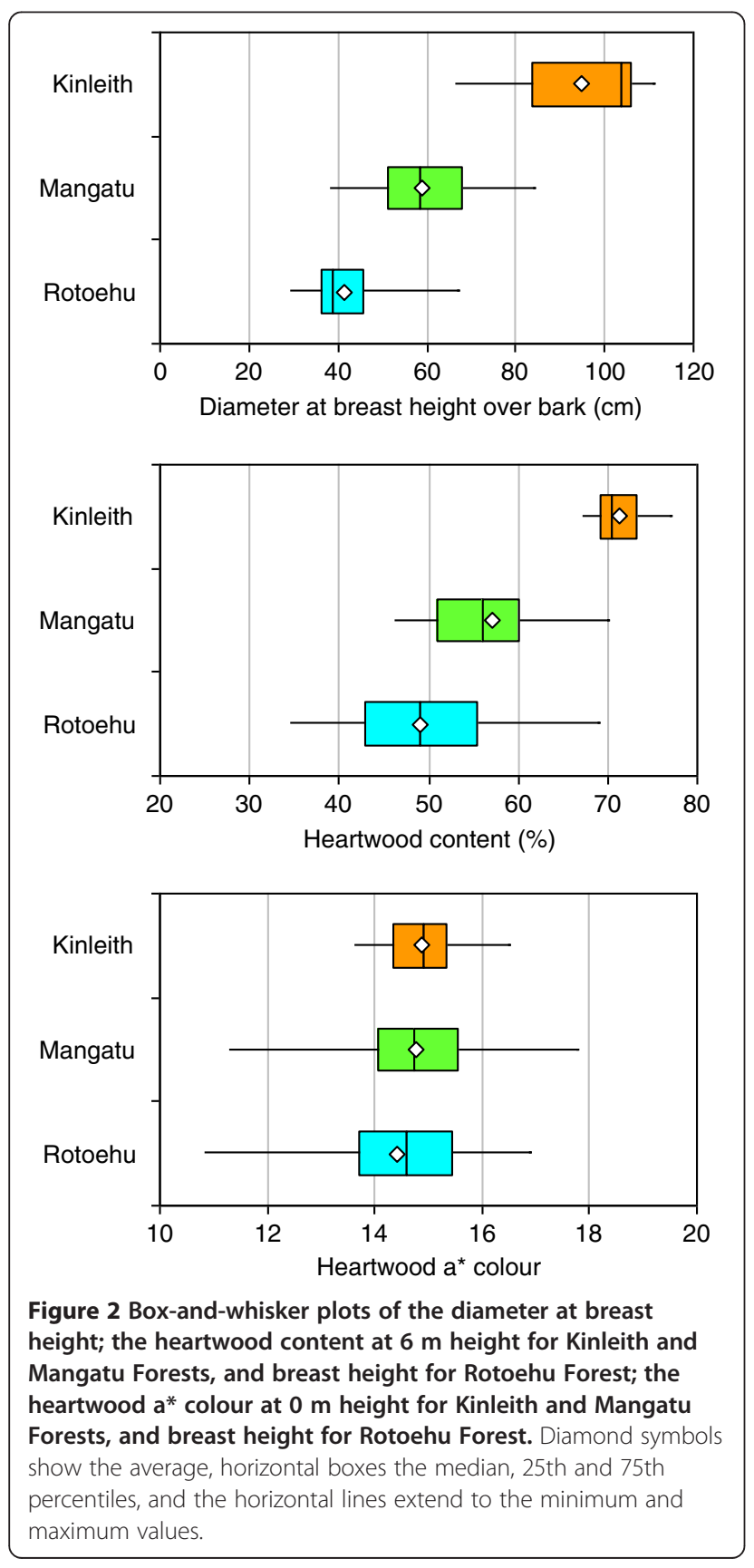

\section{Basic density}

The basic density of the wood of the coast redwood trees at Kinleith and Mangatu Forests was similar for growth rings 21-30 from the pith, at $0 \mathrm{~m}$ and $6 \mathrm{~m}$ height, but was lower at Rotoehu Forest due to the younger age of the trees (Table 5, Figure 4). Most of the variation in basic density at the Kinleith and Mangatu Forest stands occurred among the trees, with some variation within the butt log due to the small decline in basic density from $0 \mathrm{~m}$ and $6 \mathrm{~m}$ height (Table 4 ).

\section{Heartwood red colour}

The heartwood red or a* colour was very similar for the forest stands (Table 3, Figure 2). Most of the variation in the heartwood $a^{*}$ colour occurred among the trees and within the tree stems, from the inner to outer heartwood (Table 4). There were significant differences in the heartwood $a^{*}$ colour of the trees, and from the inner to outer heartwood, and a significant tree $\times$ radial position interaction (Table 6). The radial trends of heartwood $a^{*}$ colour were not consistent from the inner to outer heartwood, but varied among the individual trees, with an increase or decrease, or little change in the heartwood $\mathrm{a}^{*}$ colour from the inner to outer heartwood.

\section{Weight loss of wood blocks with decay testing}

The heartwood of the coast redwood trees was resistant to decay by the brown-rot (Gloeophyllum trabeum) and white-rot (Trametes versicolor) fungal cultures, but was

Table 4 Sources of variation in diameter growth, heartwood content, and basic density for the coast redwood trees at Kinleith, Mangatu, and Rotoehu Forest

\begin{tabular}{llll}
\hline Property & \multicolumn{3}{c}{ Variance components (\%) } \\
\cline { 2 - 4 } & Forest & Tree & Within tree \\
\hline Diameter at breast height & 83 & 17 & \\
Heartwood content $^{1}$ & 67 & 33 & 64 \\
Heartwood a* colour $^{2}$ & 0 & 36 & 36 \\
Basic density $^{3}$ & 0 & 64 & 36
\end{tabular}

${ }^{1}$ Heartwood content at $6 \mathrm{~m}$ height for Kinleith and Mangatu Forests, and breast height for Rotoehu Forest.

${ }^{2}$ Heartwood $\mathrm{a}^{*}$ colour at $0 \mathrm{~m}$ height for Kinleith and Mangatu Forests, and breast height for Rotoehu Forest.

${ }^{3}$ Basic density (rings 21-30) at $0 \mathrm{~m}$ and $6 \mathrm{~m}$ height for Kinleith and Mangatu Forests, and pith-to-bark at breast height for Rotoehu Forest 


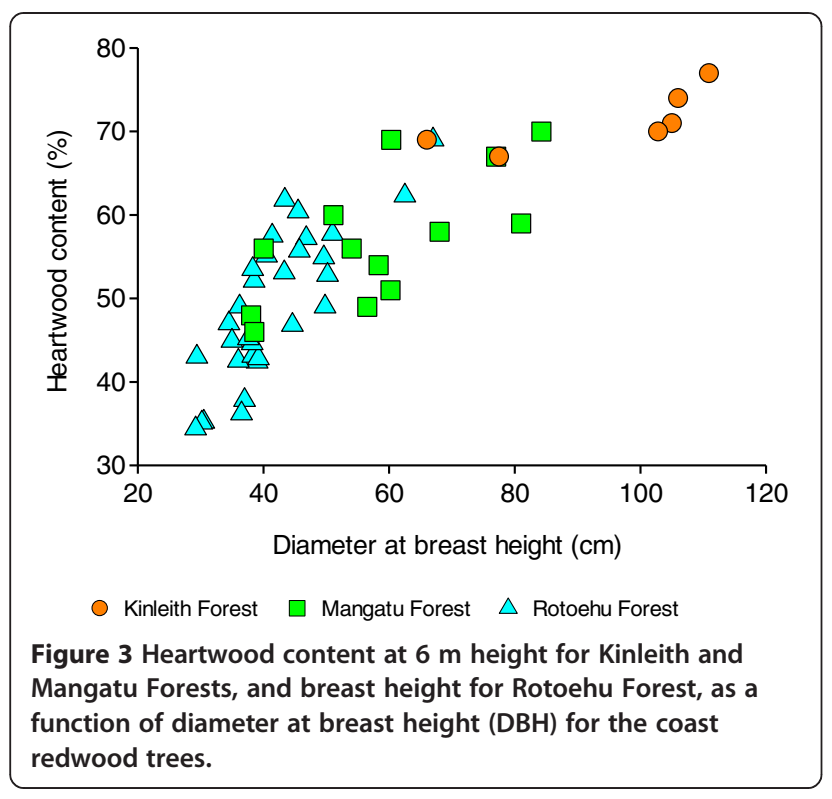

less resistant to decay by the brown-rot (Coniophora puteana) fungal culture (Table 7, Figure 5). The heartwood of the trees from the Kinleith and Mangatu Forest stands had greater resistance to fungal decay, as measured by the weight loss, which can be attributed to the older age of the trees in these stands. Most of the variation in the weight loss of the heartwood at Kinleith and Mangatu Forests occurred within the trees, from the inner to outer heartwood (Table 8, Figure 6). There was a consistent radial trend of decreasing weight loss from the inner to outer heartwood, with no significant tree $x$ radial position interaction for the trees at Kinleith and Mangatu Forests (Table 9).

The heartwood weight loss with the brown-rot $(C$. puteana) fungal culture was high for the first ten growth rings from the pith (Figure 6), but showed a large decrease over these growth rings, and was much lower for growth rings 11 to 40 from the pith. The radial trends of weight loss were similar for the forest stands at the same growth rings, which suggests the stand differences were largely due to the age of the trees. The individual trees of coast redwood from the Rotoehu Forest stand showed large differences in heartwood weight loss for the first ten growth rings from the pith (Figure 7), with some of the

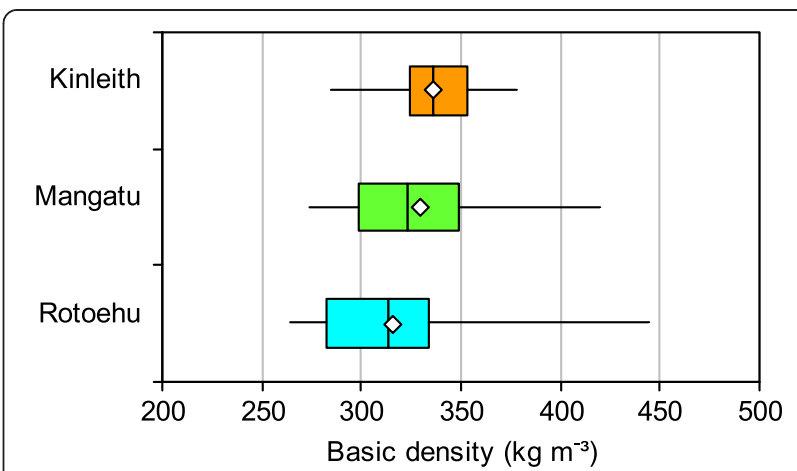

Figure 4 Box-and-whisker plots of the basic density of the wood at $0 \mathrm{~m}$ height for Kinleith and Mangatu Forests, and breast height for Rotoehu Forest. Diamond symbols show the average, horizontal boxes the median, 25th and 75th percentiles, and the horizontal lines extend to the minimum and maximum values.

trees having lower heartwood weight loss from an early age. There were significant differences in the heartwood weight loss of individual trees in the Mangatu and Rotoehu forest stands, at the same growth rings from the pith.

The coast redwood heartwood blocks were assigned to natural durability classes, based on the weight loss with the brown-rot (C. puteana) fungal culture (Table 10). The frequency of the heartwood blocks in each natural durability class varied widely for the coast redwood stands. The very durable and durable (class $1 \& 2$ ) heartwood comprised $72 \%$ and $56 \%$ of the heartwood blocks at $0 \mathrm{~m}$ height in Kinleith and Mangatu Forests, respectively, and $26 \%$ of the heartwood blocks at breast height in Rotoehu Forest. The slightly durable and not durable (class 4 \& 5) heartwood comprised $7 \%$ and $22 \%$ of the heartwood blocks at $0 \mathrm{~m}$ height in Kinleith and Mangatu Forests, respectively, and $48 \%$ of the heartwood blocks at breast height in Rotoehu Forest. The differences can be attributed to the greater proportion of the more durable outer heartwood in the older trees at Kinleith and Mangatu Forests, compared with the younger trees at Rotoehu Forest.

\section{Discussion}

The heartwood content was high for the coast redwood trees from the North Island forests, and particularly for

Table 5 Basic density of the wood of the coast redwood trees, showing forest averages with ranges of tree values in brackets

\begin{tabular}{|c|c|c|c|c|}
\hline \multirow[t]{2}{*}{ Forest } & \multirow[t]{2}{*}{ Tree age (years) } & \multicolumn{3}{|c|}{ Basic density of wood $\left(\mathrm{kg} \mathrm{m}^{-3}\right)$} \\
\hline & & $0 \mathrm{~m}$ height (rings 21-30) & Breast height (disc) & $6 \mathrm{~m}$ height (rings $21-30$ ) \\
\hline Kinleith & 71 & $359(321-436) a$ & & $336(285-378) a$ \\
\hline Mangatu & 38 & $364(278-453)$ a & & $329(274-420)$ a \\
\hline Rotoehu & 22 & & $316(264-444)$ & \\
\hline
\end{tabular}

Average values followed by the same letter do not differ significantly $(p>0.05)$. 
Table 6 Analysis of variance for heartwood a* colour, showing the significance of the main and interactive effects of tree and radial position from inner to outer heartwood

\begin{tabular}{|c|c|c|c|c|c|c|}
\hline \multirow[t]{2}{*}{ Source of variation } & \multicolumn{3}{|c|}{ Kinleith Forest ${ }^{1}$} & \multicolumn{3}{|c|}{ Mangatu Forest $^{1}$} \\
\hline & $\mathrm{DF}$ & $F$-value & $P$-value & DF & $F$-value & $P$-value \\
\hline Tree & 4,45 & 15.7 & $<.0001$ & 12,48 & 11.5 & $<.0001$ \\
\hline Radial position & 3,45 & 3.3 & 0.030 & 3,48 & 12.2 & $<.0001$ \\
\hline Tree $\times$ Radial position & 11,45 & 10.4 & $<.0001$ & 27,48 & 2.2 & 0.009 \\
\hline
\end{tabular}

${ }^{1}$ Heartwood $\mathrm{a}^{*}$ colour at $0 \mathrm{~m}$ height for Kinleith and Mangatu Forests.

the larger trees in each of the stands. Heartwood development is age related, and progresses outward at a set fraction of the annual increment, and in the larger trees where growth is faster and the rings are wider, more heartwood is produced (Wilkes 1991; Cown 1999). A large proportion of the variation in the heartwood content of the coast redwood trees at Mangatu and Rotoehu Forests can be attributed to the differences in tree diameter. Faster growth of coast redwood in New Zealand is likely to increase the heartwood content, and with the large variation in heartwood content among trees there could be opportunities for gains from genetic selection. The heartwood content is under strong genetic control in pine and larch species, and the broad-sense heritability of the heartwood content is high in larch (Magnussen and Keith 1990; Pâques 2001). The selection and use of clones of coast redwood in the plantation forests of New Zealand could lead to gains in both growth and heartwood content.

The basic density of the wood of coast redwood trees in the North Island forests was comparable with secondgrowth coast redwood trees in California, USA. The stocking rates and basal area of the Kinleith and Mangatu Forest stands was indicative of closely grown trees, and could explain the similar wood basic density of these stands, when compared at the same growth rings. The stocking rates of coast redwood stands has a noticeable effect on the basic density, as shown by the lower average basic density of openly grown trees compared with closely grown trees $\left(310-318\right.$ versus $356-360 \mathrm{~kg} \mathrm{~m}^{-3}$ ) of second-growth coast redwood in California, USA (Luxford and Markwardt 1932; Markwardt and Wilson 1935). This suggests that stand density after thinning of 400 to 600 stems $\mathrm{ha}^{-1}$ could be needed in New Zealand to meet the basic density requirements of wood products such as decking and weatherboards. Durability tests of coast redwood weatherboards in New Zealand have shown moderate weathering after test periods of 9 to 17 years (Page et al. 1997), which suggests that surface wear will be an issue for low density boards. The wide range of basic density evident among the coast redwood trees of the North Island forests, suggests there could be some potential for the selection of clones with wood of higher basic density.

The range of heartwood $a^{*}$ colour of the coast redwood trees in the North Island forests, was consistent with the wide degree of natural variability in the shade and intensity of heartwood colour in the coast redwood trees in California, USA (Wilcox and Piirto 1976). Much of the variation in the heartwood $\mathrm{a}^{*}$ colour occurred within the stems of the trees, from the inner to outer heartwood. This can be expected to give variable patterns of heartwood $a^{*}$ colour in the boards cut from the trees. There were differences in heartwood $a^{*}$ colour among trees, and also differences in the pattern of within-tree heartwood $a^{*}$ colour variation, from the inner to outer heartwood. This suggests that genetic selection for heartwood $\mathrm{a}^{*}$ colour in coast redwood trees will need to consider the radial patterns of variation. Heartwood colour has been found to be under genetic control in Eucalyptus dunnii Maiden (Vanclay et al. 2008) and Acacia melanoxylon R.Br. (Bradbury et al. 2011), with some genetic control of within-tree colour variation (Bradbury et al. 2011). Environmental factors have also been found to affect heartwood colour in

Table 7 Comparison of the weight loss for the heartwood blocks of coast redwood, and sapwood blocks of radiata pine

\begin{tabular}{lllll}
\hline \multirow{2}{*}{ Species } & Forest and disc & \multicolumn{3}{c}{ Weight loss of blocks (\%) } \\
\cline { 3 - 5 } & & Brown rot C. puteana & Brown rot G. trabeum & White rot T. versicolor \\
\hline Coast redwood & Kinleith - $0 \mathrm{~m}$ & $9.0 \mathrm{~b}$ & $1.2 \mathrm{~b}$ & $0.8 \mathrm{~b}$ \\
& Kinleith - $6 \mathrm{~m}$ & $12.6 \mathrm{~b}$ & $1.5 \mathrm{~b}$ & $0.6 \mathrm{~b}$ \\
& Mangatu - $0 \mathrm{~m}$ & $12.0 \mathrm{~b}$ & $2.4 \mathrm{~b}$ & $1.8 \mathrm{a}$ \\
& Rotoehu - BH & $21.5 \mathrm{a}$ & $4.9 \mathrm{a}$ & $2.2 \mathrm{a}$ \\
Radiata pine & & 35.5 & 38.5 & 11.3 \\
\hline
\end{tabular}

Average values followed by the same letter do not differ significantly for each fungal culture $(p>0.05)$. 


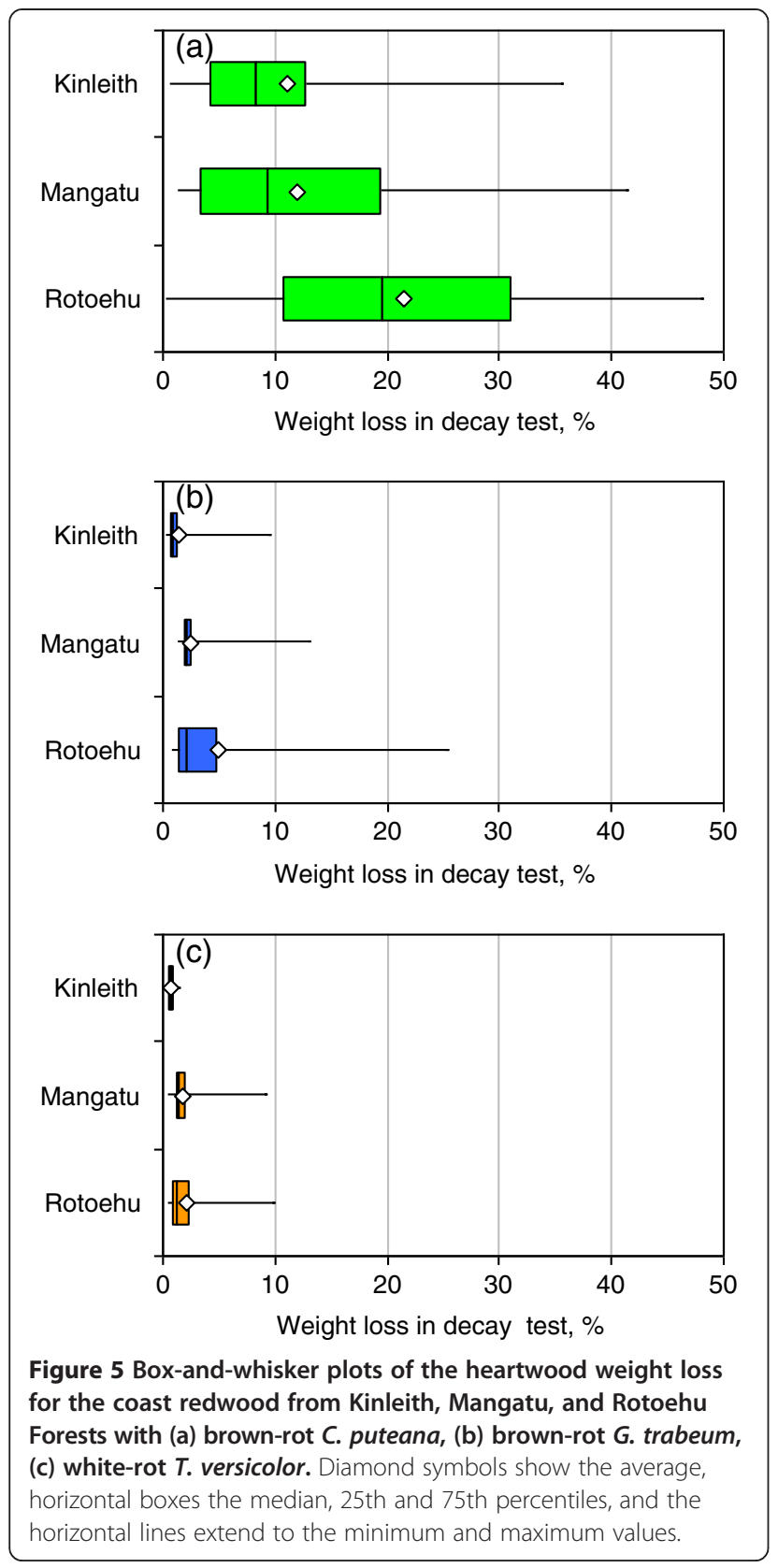

Table 8 Sources of variation in the weight loss of the heartwood blocks of coast redwood with the brown- and white-rot fungal cultures, for the Kinleith and Mangatu Forest tree butt $(0 \mathrm{~m})$ height discs

\begin{tabular}{llll}
\hline Fungal culture & \multicolumn{3}{l}{ Variance components (\%) } \\
\cline { 2 - 4 } & Forest & Tree & Block \\
\hline Brown-rot (C. puteana) & 0 & 2 & 98 \\
Brown-rot (G. trabeum) & 21 & 3 & 76 \\
White-rot (T. versicolour) & 24 & 5 & 71 \\
\hline
\end{tabular}

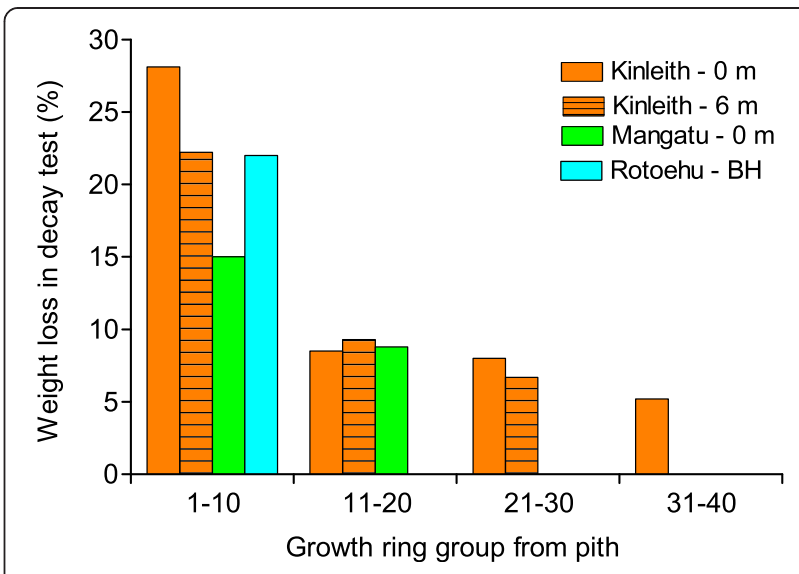

Figure 6 Weight loss for growth ring number from the pith, with the brown-rot (C. puteana) fungal culture, for the coast redwood trees from Kinleith, Mangatu, and Rotoehu Forests.

Acacia melanoxylon (Bradbury et al. 2011) and Juglans nigra L. (Rink 1987), and to interact with the genetic control of heartwood colour in Acacia melanoxylon (Bradbury et al. 2011). While the North Island forest sites had no noticeable effect on the heartwood a* colour of the coast redwood trees, the selection of clones for heartwood colour may require testing for the expression of heartwood colour in different environments.

The decrease in the weight loss with fungal decay testing, from the inner to outer heartwood of the coast redwood trees, was similar to the radial trends observed in the heartwood of 45 to 64 year-old second-growth coast redwood trees (Sherrard and Kurth 1933), and 24 to 100 year-old second-growth coast redwood trees (Clark and Scheffer 1983) in California, USA. This has been attributed to an increase in the content and toxicity of the extractives from the inner to outer heartwood (Sherrard and Kurth 1933). The weight loss was similar for the same growth rings from the pith, for trees of different age in the North Island forest stands, which suggests the radial trends of weight loss were closely related to the age of heartwood formation. Most of the radial change in weight loss occurred in the first ten growth rings from the pith, with little change in the weight loss of

Table 9 Analysis of variance for weight loss of the heartwood blocks of coast redwood, with the brown-rot (C. puteana) fungal culture, showing the significance of the main and interactive effects of tree and radial position from inner to outer heartwood

\begin{tabular}{|c|c|c|c|c|c|c|}
\hline \multirow[t]{2}{*}{ Source of variation } & \multicolumn{3}{|c|}{ Kinleith forest $^{1}$} & \multicolumn{3}{|c|}{ Mangatu forest ${ }^{1}$} \\
\hline & DF & $F$-value & $P$-value & $\mathrm{DF}$ & $F$-value & $P$-value \\
\hline Tree & 3,1 & 12.2 & 0.21 & 12,13 & 3.8 & 0.011 \\
\hline Radial position & 3,1 & 22.5 & 0.15 & 3,13 & 11.7 & 0.001 \\
\hline Tree $\times$ radial position & 6,1 & 6.3 & 0.30 & 21,13 & 0.8 & 0.664 \\
\hline
\end{tabular}

${ }^{1}$ Heartwood weight loss at $0 \mathrm{~m}$ height for Kinleith and Mangatu Forests. 


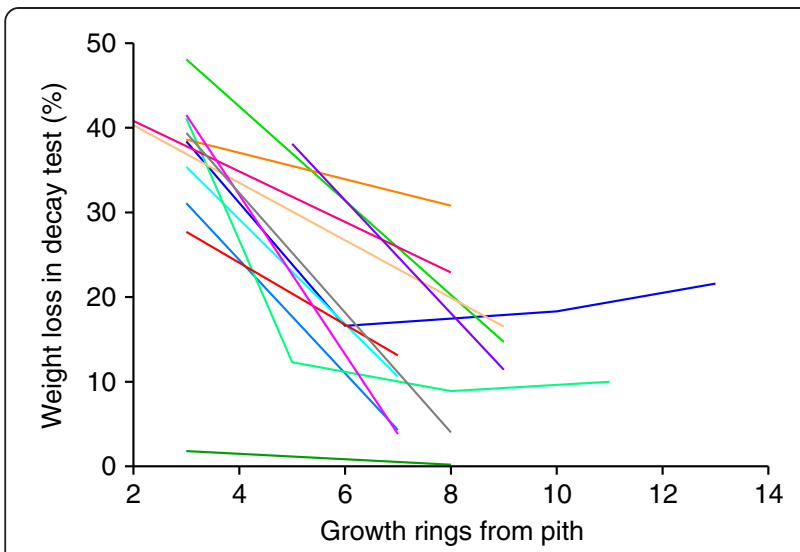

Figure 7 Weight loss for growth ring number from the pith, with the brown-rot (C. puteana) fungal culture, for the coast redwood trees from Rotoehu Forest. The coloured lines each represent an individual tree.

heartwood in growth rings 11 to 40 from the pith. The higher proportion of durable heartwood in the older trees can be attributed to the greater content of heartwood in the outer growth rings. This indicates the use of longer rotations for coast redwood in New Zealand will have the benefit of producing greater quantities of durable heartwood.

There was variation among trees in the weight loss of heartwood at the same growth rings, which suggests there is potential to select coast redwood trees for increased durability. The durability of heartwood is under genetic control in larch and pine. The heartwood of clonal trees of Siberian larch (Larix sibirica Ledeb.) showed moderate broad-sense heritability (Venäläinena et al. 2005), and the heartwood of Scots pine (Pinus sylvestris $\mathrm{L}$.) trees showed moderate narrow-sense heritability (Harju and Venäläinena 2002), for durability against the brown-rot decay fungus Coniophora puteana. The heartwood of coast redwood trees should be selected for durability on the basis of the same heartwood growth rings. The inner heartwood in the first ten growth rings from the pith has the greatest potential for improvement in durability. The consistent radial trend in coast redwood trees of declining weight loss from inner to outer heartwood, suggests that selection for improved durability of the inner heartwood is likely to improve the durability of the outer heartwood.

The brown-rot (C. puteana and G. trabeum) and white-rot ( $T$. versicolor) test fungi used in this study are known to represent the decay hazard that is observed on buildings in Europe (Van Acker et al. 1999). Brown-rot fungi usually occur on softwoods, such as coast redwood, which has been attributed to their ability to utilise the hemicelluloses present in softwoods (Highley 1987). This would explain the higher weight loss of the heartwood of coast redwood with the brown-rot fungi in the decay testing. The durability classes of the heartwood of coast redwood in this study will be applicable to aboveground exterior use as weatherboards and decking, but not to high decay hazards involving contact with soil, where soft-rots and other types of micro-organisms will be present.

\section{Conclusions}

The wood properties of plantation-grown coast redwood in New Zealand showed large variation among and within trees in the forest stands. The heartwood content increased with larger tree diameter in the forest stands, which suggests that faster diameter growth is likely to increase the heartwood content. The basic density of the wood varied widely among the trees in the forest stands, and was comparable with secondgrowth coast redwood trees in California. The heartwood $a^{*}$ colour showed radial variation within the tree stems, that will give variable patterns of colour in boards cut from the trees.

The durability of the heartwood, with fungal decay testing, showed strong radial trends that were closely related to the age of heartwood formation. The increase in durability from the inner to outer heartwood was similar to that observed in second-growth coast redwood in California. Older trees had a higher proportion of the more durable outer heartwood, which suggests that longer rotations for coast redwood in New Zealand will have the benefit of producing greater quantities of durable heartwood.

Table 10 Proportion of the heartwood blocks in each durability class, for the Kinleith, Mangatu, and Rotoehu Forest tree discs, according to European standard EN 350-1 (1994) after decay testing with the brown-rot (C. puteana) fungal culture

\begin{tabular}{lllll}
\hline Durability class & \multicolumn{4}{c}{ Proportion of heartwood blocks (\%) } \\
\cline { 2 - 5 } & Kinleith $\mathbf{0}$ m height & Kinleith $\mathbf{~} \mathbf{~ m}$ height & Mangatu 0 $\mathbf{~ m}$ height & Rotoehu breast height \\
\hline 1 - Very durable & 29 & 41 & 38 & 12 \\
2 - Durable & 43 & 18 & 18 & 14 \\
3 - Moderately durable & 21 & 18 & 22 & 26 \\
4 - Slightly durable & 7 & 9 & 16 & 24 \\
5 - Not durable & 0 & 14 & 6 & 24 \\
\hline
\end{tabular}




\section{Endnote}

${ }^{a}$ Effective stand density is measured by subtracting a given proportion of the forest area, to account for gaps in the forest canopy. The survival of the trees in the Rotoehu Forest stand was variable, due to weed competition during establishment, so the effective stand density is a more appropriate measure of the density of the trees than actual stand density in a given area.

\section{Competing interests}

The authors declare that they have no competing interests.

\section{Authors' contributions}

TJ organised the study, carried out the analysis, and wrote the manuscript. $\mathrm{CL}$ provided advice on the design of the study, and DO and CC carried out the fungal decay testing. All authors read and approved the final manuscript.

\section{Acknowledgements}

We thank Dave Page (Scion) for preparing the wood blocks for fungal decay testing, Paul Silcock (New Zealand Forestry Ltd) for providing the butt log discs of the Mangatu Forest coast redwood trees, and Simon Rapley (The New Zealand Redwood Company) and Rob Webster (New Zealand Forestry Ltd) for information on the Kinleith Forest coast redwood trees. The research was funded by Future Forests Research (FFR) Ltd, through the Foundation for Research, Science and Technology - Contract No. C04X0805.

\section{Author details}

${ }^{1}$ The New Zealand Institute for Plant \& Food Research Limited, Private Bag 11600, Palmerston North 4442, New Zealand. ${ }^{2}$ Scion, Private Bag 3020, Rotorua, New Zealand.

\section{Received: 18 November 2012 Accepted: 25 March 2014}

Published online: 25 June 2014

\section{References}

Bendtsen, BA. (1966). Strength and related properties of a randomly selected sample of second -growth redwood. United States Forest Service Research Paper FPL 53.

Bradbury, G, Potts, BM, Beadle, CL, Dutkowski, G, \& Hamilton, M. (2011). Genetic and environmental variation in heartwood colour of Australian blackwood (Acacia melanoxylon R.Br.). Holzforschung, 65(3), 349-359.

Brown, I. (2007). Redwoods - an overview. New Zealand Tree Grower, February, 4-5.

CIE. (2007). CIE Colorimetry - Part 4: $1976 L^{*} a^{*} b^{*}$ Colour Space. Joint ISO/CIE Standard, ISO 11664-4:2008(E)/CIE S 014-4/E:2007. Vienna, Austria: CIE Central Bureau.

Clark, JW, \& Scheffer, TC. (1983). Natural decay resistance of the heartwood of coast redwood Sequoia sempervirens (D. Don) Endl. Forest Products Journal, 33 (5), 15-20.

Colbert, CM, \& McConchie, DL. (1983). Some physical properties of New Zealandgrown redwood. (FRI Bulletin No. 124). Rotorua, New Zealand: New Zealand Forest Research Institute.

Cown, DJ. (1999). New Zealand pine and Douglas-fir - Suitability for processing. (Forest Research Bulletin No. 216). Rotorua, New Zealand: New Zealand Forest Research Institute Limited.

Cown, DJ. (2008). Redwood in New Zealand - an end-user perspective. New Zealand Journal of Forestry, 52(4), 35-41.

Cown, DJ, \& McKinley, RB. (2009). Wood properties of 38-year-old redwood from Mangatu Forest. New Zealand Journal of Forestry, 54(2), 25-32.

Cown, DJ, Marshall, H, Silcock, P, \& Meason, D. (2013). Sawn timber grade recovery from a planted coast redwood stand growing in New Zealand. New Zealand Journal of Forestry Science, 43(8), 1-11.

Dean, M. (2007). Coast redwood silviculture in New Zealand. New Zealand Tree Grower, February, 6-7.

EN 113. (1996). Wood preservatives - Test method for determining the protective effectiveness against wood destroying basidiomycetes: determination of the toxic values. Brussels: European Committee for Standardization.

EN 350-1. (1994). Durability of wood and wood-based products - Natural durability of solid wood - Part 1: guide to the principles of testing and classification of the natural durability of wood. Brussels: European Committee for Standardization.
EN 84. (1997). Wood preservatives - Accelerated ageing of treated wood prior to biological testing - Leaching procedure. Brussels: European Committee for Standardization.

Fritz, E. (1950). Mechanical properties of second-growth redwood and comparison with virgin timber. (ASTM Bulletin No. 169), 30-32.

Harju, AM, \& Venäläinena, M. (2002). Genetic parameters regarding the resistance of Pinus sylvestris heartwood to decay caused by Coniophora puteana. Scandinavian Journal of Forest Research, 17(3), 199-205.

Haslett, AN, \& Young, GD. (1990). Plantation grown tropical timbers 1. Wood property and processing evaluation procedures to improve usage. Journal of Tropical Forest Science, 3(2), 131-139.

Highley, TL. (1987). Changes in chemical components of hardwood and softwood by brown-rot fungi. Material und Organismen, 22(1), 39-45.

Hughes, C. (1982). The natural durability of untreated timbers. What's new in forest research, No. 112. Rotorua, New Zealand: New Zealand Forest Research Institute.

Knowles, FB, \& Miller, JT. (1993). Introduced forest trees in New Zealand: recognition, role and seed source. 13. The Redwoods. Sequoia sempervirens (D. Don) Endl. coast redwood, Sequoiadendron giganteum (Lindley) J. Buchholz - giant sequoia, and the related ornamental genera Taxodiurn and Metasequoia. (FRI Bulletin No. 124). Rotorua, New Zealand: New Zealand Forest Research Institute Limited.

Littell, RC, Milliken, GA, Stroup, WW, \& Wolfinger, RD. (1996). SAS system for mixed models. Cary, North Carolina: SAS Institute Inc.

Luxford, RF, \& Markwardt, LJ. (1932). The strength and related properties of redwood. (United States Department of Agriculture Technical Bulletin No. 305).

Magnussen, S, \& Keith, CT. (1990). Genetic improvement of volume and wood properties of Jack pine: Selection strategies. The Forestry Chronicle, 66(3), 281-286.

Markwardt, LJ, \& Wilson, TRC. (1935). Strength and related properties of woods grown in the United States, (United States Department of Agriculture Technical Bulletin No. 479).

Nicholas, I. (2008). Best Practice with Farm Forestry Timber Species, No. 3: Redwoods. NZFFA electronic handbook series No. 3.

Page, D, Foster, J, \& Hedley, M. (1997). Naturally durable wood - is it a practical alternative to preservative-treated pine? What's new in forest research, No. 245. Rotorua, New Zealand: New Zealand Forest Research Institute.

Pâques, LE. (2001). Genetic control of heartwood content in larch. Silvae Genetica, $50(2), 69-75$.

Resch, H, \& Arganbright, DG. (1968). Variation of specific gravity, extractive content, and tracheid length in redwood trees. Forest Science, 14(2), 148-155.

Rink, G. (1987). Heartwood color and quantity variation in a young black walnut progeny test. Wood and Fiber Science, 19(1), 93-100.

Sherrard, EC, \& Kurth, EF. (1933). Distribution of extractive in redwood, its relation to durability. Industrial and Engineering Chemistry, 25(3), 300-302.

Van Acker, J, Militz, H, \& Stevens, M. (1999). The significance of accelerated laboratory testing methods determining the natural durability of wood. Holzforschung, 53(5), 449-458.

Vanclay, JK, Henson, M, \& Palmer, G. (2008). Color variation and correlations in Eucalyptus dunnii sawnwood. Journal of Wood Science, 54(6), 431-435.

Venäläinena, M, Harju, AM, Nikkanen, T, Paajanen, L, Velling, P, \& Viitanen, H. (2005). Genetic variation in the decay resistance of Siberian larch (Larix sibirica Ledeb.) wood. Holzforschung, 55(1), 1-6.

Vincent, G. (2001). Coast Redwood - Results from a 20-year-old trial. New Zealand Tree Grower.

Wilcox, WW, \& Piirto, DD. (1976). Decay resistance in redwood (Sequoia sempervirens) heartwood as related to color and extractives. Wood and Fiber, $7(4), 240-245$.

Wilkes, J. (1991). Heartwood development and its relationship to growth in Pinus radiata. Wood Science and Technology, 25(2), 85-90.

doi:10.1186/s40490-014-0011-x

Cite this article as: Jones et al:: Variation in the wood properties of coast redwood trees in New Zealand. New Zealand Journal of Forestry Science 2014 44:11. 